основании патента в соответствии со статьей 227.1 Налогового кодекса Российской Федерации:

11 160,5 тыс. рублей х 115,1\%=12 845,7 тыс. рублей, где:

11 160,5 тыс. рублей - ожидаемое поступление налога в 2017 году, рассчитанное исходя из поступлений в I полугодии 2017 года;

115,1\% - ожидаемый темп роста поступлений налога 2017 года к 2016.

Прогноз поступления налога на доходы физических лиц в бюджет города на 2018 год:

3025 145,6 тыс. рублей +12 845,7 тыс. рублей = 3037 991,3 тыс. рублей.

На наш взгляд, данный алгоритм расчета является наиболее результативным на основе располагаемой информации.

$$
* * *
$$

1. Вершинин Ю.Б., Вершинина Е.Л. О мерах по обеспечению финансирования основных статей бюджета муниципального образования «Город Ульяновск». Научный диалог: Экономика и менеджмент. Сборник научных трудов по материалам VI международной научной конференции. Санкт-Петербург, 08 мая 2017 г. Издательство: Центр научных конференций Международной научно-исследовательской Федерации "Общественная наука" Страницы: 9-10 DOI: 10.18411/spc8-05-2017-04

2. Вершинин Ю.Б., Вершинина Е.Л. О соотношении доходных поступлений в бюджет муниципального образования «Город Ульяновск» с его расходными обязательствами. Научный диалог: Экономика и менеджмент. Сборник научных трудов по материалам VI международной научной конференции. Санкт-Петербург, 08 мая 2017 г. DOI: 10.18411/spc-8-05-2017-03

\title{
Вершинин Ю.Б., Вершинина Е.Л. \\ О прогнозировании доходов от использования имущества, находящегося в государственной и муниципальной собственности города Ульяновска
}

Ульяновский государственный университет (Россия, Ульяновск)

doi:10.18411/spc-8-11-2017-06

idsp: 000001:spc-8-11-2017-06

Резкое снижение неналоговых доходов за последние годы стало серьезной проблемой для большинства муниципалитетов [2]. Общие неналоговые доходы в рассматриваемом периоде прогнозируются нами с существенным сокращением [1], в т.ч. и доходы от использования городского имущества в сумме 328566,9 тыс. рублей (рис.1.), в том числе:

- доходы, получаемые в виде арендной платы за земельные участки, государственная собственность на которые не разграничена и которые расположены в границах городских округов, а также средства от продажи права на заключение договоров аренды указанных земельных участков 236 700,0 тыс. рублей;

- доходы, получаемые в виде арендной платы, а также средства от продажи права на заключение договоров аренды за земли, находящиеся в собственности городских округов (за исключением земельных участков муниципальных бюджетных и автономных учреждений) - 3 740,0 тыс. рублей (согласно прогнозным данным администратора поступлений Управления муниципальной собственностью администрации города Ульяновска);

- доходы от сдачи в аренду имущества, составляющего казну городских округов (за исключением земельных участков) - 65 533,3 тыс. рублей, согласно прогнозным данным Управления муниципальной собственностью администрации города Ульяновска; 


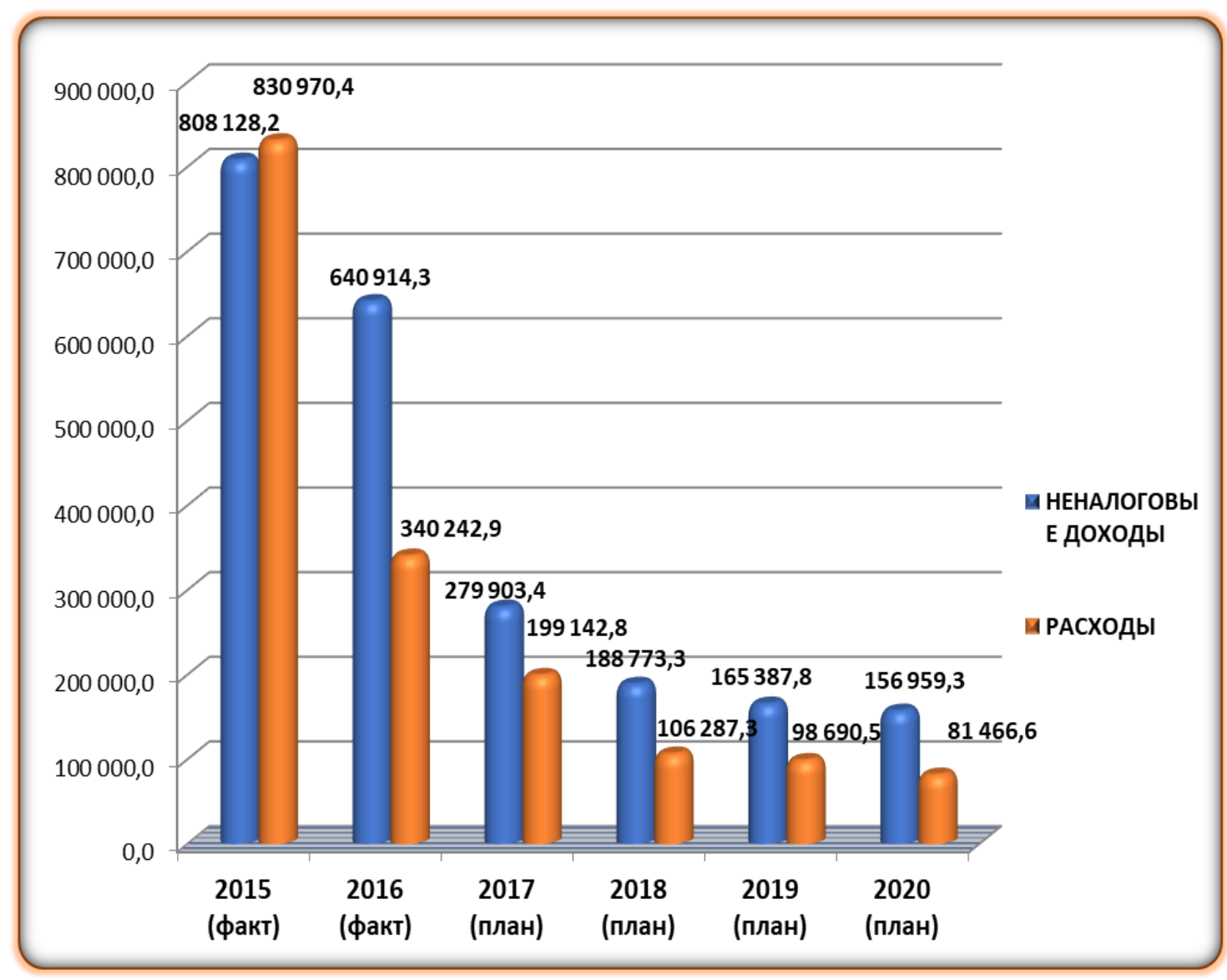

Рис.1. Поступление доходов от использования имущества, находящегося в государственной и муниципальной собственности в 2015-2020 г2. (прогноз).

- прочие поступления от использования имущества, находящегося в собственности городских округов (за исключением имущества муниципальных бюджетных и автономных учреждений, а также имущества муниципальных унитарных предприятий, в том числе казённых) - 20 693,6 тыс. рублей.

- доходы от перечисления части прибыли, остающейся после уплаты налогов и иных обязательных платежей муниципальных унитарных предприятий, созданных городскими округами - 1 900,0 тыс. рублей, согласно прогнозным данным Управления муниципальной собственностью администрации города Ульяновска;

1. Вершинин Ю.Б., Вершинина Е.Л. О мерах по обеспечению финансирования основных статей бюджета муниципального образования «Город Ульяновск». Научный диалог: Экономика и менеджмент. Сборник научных трудов по материалам VI международной научной конференции. Санкт-Петербург, 08 мая 2017 г. Стр. 9-10 DOI: 10.18411/spc-8-05-2017-04

2. Вершинин Ю.Б., Вершинина Е.Л. О соотношении доходных поступлений в бюджет муниципального образования «Город Ульяновск» с его расходными обязательствами. Научный диалог: Экономика и менеджмент. Сборник научных трудов по материалам VI международной научной конференции. Санкт-Петербург, 08 мая 2017 г. DOI: 10.18411/spc-8-05-2017-03 